\title{
Catch per unit effort-environmental variables relations in the fishery of white shrimp (Litopenaeus schmitti) from the Gulf of Venezuela
}

\author{
Ángel Antonio Díaz Lugo ${ }^{1}$, Orlando José Ferrer Montaño ${ }^{2^{*}}$, Rodolfo Álvarez ${ }^{1}$, \\ Luis González ${ }^{1}$, Jesús Méndez ${ }^{1}$, Manuel Corona ${ }^{3}$ \\ ${ }^{1}$ Instituto Nacional de Investigaciones Agropecuarias (INIA), Punto Fijo, Venezuela \\ ${ }^{2}$ Departamento de Biología, Universidad del Zulia, Maracaibo, Venezuela; ${ }^{*}$ Corresponding Author: carichuano@hotmail.com \\ ${ }^{3}$ Instituto Socialista de la Pesca y la Acuicultura (INSOPESCA), Caracas, Venezuela
}

Received 12 March 2013; revised 13 April 2013; accepted 1 May 2013

Copyright (C) 2013 Ángel Antonio Díaz Lugo et al. This is an open access article distributed under the Creative Commons Attribution License, which permits unrestricted use, distribution, and reproduction in any medium, provided the original work is properly cited.

\section{ABSTRACT}

During 15 months the white shrimp (Litopenaeus schmitti) fishing zone was characterized ecologically through the obtaining, compilation and analysis of environmental and physicochemical variables, and modeled the distribution of the relative abundance (CPUE) obtained in 21 fishing sites according to the environmental structure defined by the studied variables. A two-way factorial ANOVA with interaction was used to examine the spatial (fishing sites) and temporal (months) dynamics of CPUE, and a principal component analysis (PCA) was used to discern the environmental structure of the study area. To determine if the environmental structure modeled the distribution of white shrimp, the CPUE values were superimposed on maps of the study area showing strata of the most important physicochemical variables identified by PCA. ANOVA confirmed that the CPUE differed significantly among months (F = 15.6; GL = 11; $P<0.0001)$ but not between fishing sites $(F=1.52 ; G L=17 ; P=$ 0.1979 ); the interaction term was also not significant $(F=0.52 ; G L=10 ; P=0.8561)$. The superimposing of the CPUE on temperature and depth strata confirmed that white shrimp showed greater preference for intermediate temperatures and depths. Petróleos de Venezuela, S.A (PDVSA) contemplates the construction of a multiuse pipeline traversing the study area, by which the current environmental structure of the study area is prone to disturbance. Given the precedent effects represented by an aqueduct construction, it seems PDVSA should anticipate measures to minimize its impact on the fisheries of the zone, particularly on the white shrimp fishery.

Keywords: Distribution; CPUE; Litopenaeus schmitti; Gulf of Venezuela

\section{INTRODUCTION}

Within recent years there has been growing emphasis on the need to assess and manage fisheries through an ecological perspective [1-3]. This perspective, called by some Ecosystem Based Fisheries Management (EBFM) and by others Ecosystem Approach to Fisheries (EAF), has been proposed as a more effective and holistic approach to the management of world fisheries [4-7]. The objective of this approach is to maintain healthy marine ecosystems and the fisheries they support, addressing some of the unintended consequences of fishing, such as habitat destruction, incidental mortality of nontarget species and changes in the structure and function of ecosystems [6].

However, the application of this perspective requires that fishery managers consider all interactions that stocks of a target species have with their predators, competitors and prey species: the effects of climate on fisheries boilogy and ecology, the complex interactions between fish and their habitats and the effects of the fishing activity on fish stocks and their habitats [8]. An initial step for the implementation of an EBFM would be to determine how the capture of a species could affect other species, or how the target species responds to the ecological reference framework of the habitat. Fisheries management 
decisions taken at this level can prevent significantly and potentially irreversible changes in marine ecosystems, caused by fishing or other anthropogenic activity [8].

The management of fisheries based on the ecosystem can be an important complement to existing management strategies. When fishery managers understand the complex ecological and socio-economic environments in which fish and fisheries exist, they can anticipate the effects that fisheries management will have on the ecosystem and the effects that changes in the ecosystem will have on fisheries. However, the ecosystem management itself cannot solve all the problems underlying the existing fisheries management regime. In the absence of political will to stop overfishing, protect habitat and support programs of research and monitoring, an ecosystem approach is not effective.

In the marine coastal zone of the Gulf of Venezuela, particularly in the area of the community of Río Seco, Falcón State, there is a very important artisanal fishery for white shrimp (Litopenaeus schmitti). The area of exploitation of this fishery was described by Zeigler [9] as a bay, with depths no greater than $50 \mathrm{~m}$, and averages in the West area not exceeding $20 \mathrm{~m}$. Likewise, due to the direct contact with the Caribbean Sea (ocean waters, up to 37 UPS), Golfete de Coro (very saline, up to 45 UPS waters) and waters of Lake Maracaibo (estuarine waters, up to $\sim 3$ UPS), it has peculiar physicochemical features [10]. Due to these characteristics, this fishing area offers a suitable environment to evaluate the effect that the environmental matrix has on the abundance and distribution of the white shrimp.

Therefore, the main objectives of this study are, firstly, to characterize ecologically the fishing area of the white shrimp (L. schmitti), whose base port is the community of Río Seco, Falcon State, through obtaining, gathering and analysis of some environmental parameters and physicochemical variables; and secondly, to determine if the environmental structure given by these variables models the distribution and abundance of the white shrimp. This information could serve as a fundamental ecological basis for the implementation of programs of management of the fishery of this species based on the perspective EBFM.

\section{MATERIALS AND METHODS}

The study area was restricted to the fishing zone of the Rio Seco community, Falcon State, located in the marine coastal zone of the Gulf of Venezuela (Figure 1). For characterizing ecologically the study area and assess the

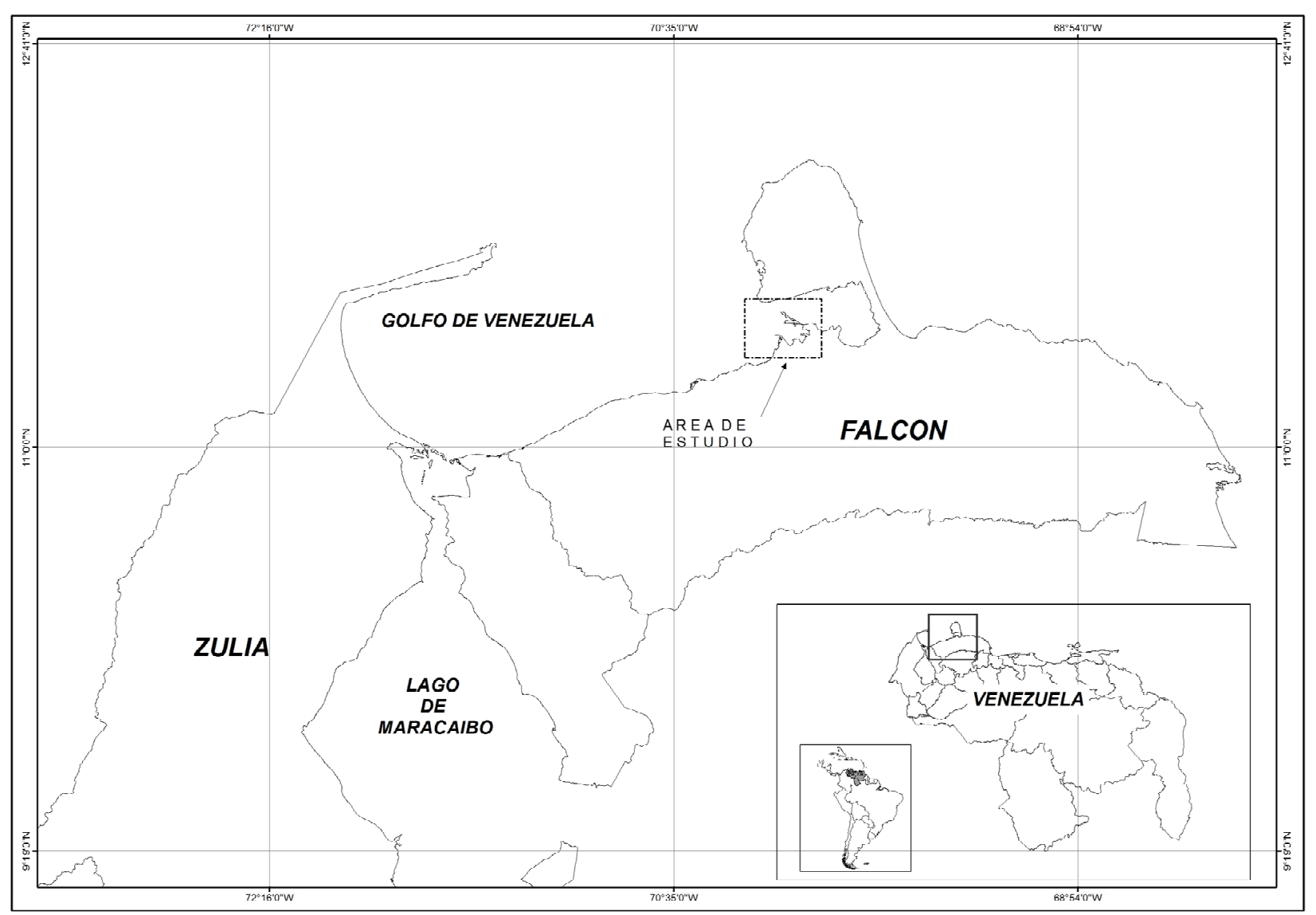

Figure 1. Study area and its relative position on the Venezuelan coast. 
abundance and distribution of the resource, 21 sites of fishing were georeferenced with a GPS Map 76CSx GARMIN, aboard of artisanal fishing boats following a haphazard experimental sampling design between September 2008-November 2009. The total area covered by the surveys was $\sim 43 \mathrm{~km}^{2}$. In each sampling, the number of captured individuals was recorded and a sample was selected for taxonomic identification according to the Perez-Farfante [11], Fisher [12] and Rodriguez [13] keys.

In each fishing site the following physicochemical variables were recorded: salinity (S; UPS), water temperature $\left(\mathrm{T},{ }^{\circ} \mathrm{C}\right)$, dissolved oxygen $(\mathrm{OD} ; \mathrm{mg} / \mathrm{l})$, oxygen percent saturation (PSO; \%), depth $(\mathrm{D}, \mathrm{m})$ and transparency (TR; $\mathrm{m})$. To obtain the variables $\mathrm{S}, \mathrm{T}, \mathrm{OD}$ and PSO at the surface and bottom, a multiparametric probe YSI 55 (YSI Incorporated, USA) was used; to obtain the depth it was used a rope numbered with a heavy object attached to it, and a Secchi disk was used to obtain transparency. Environmental parameters collected and analyzed were rainfall and winds; these were gathered from the database of the weather station located in the city of Coro, Falcon State, administered by the Department of Climatology of the Meteorological Service of the Bolivarian Military Aviation of Venezuela.

The relative abundance (catch per unit effort; CPUE in number of individuals per minute of fishing; ind $/ \mathrm{min}$ ) independently for each site and month of sampling was determined, and the temporal (month) and spatial (fishing site) dynamics were examined with a two-way factorial ANOVA with interactions, where month and fishing site were the main effects and month $\times$ fishing site was the interaction term. The level for statistical significance was set at 0.05 ; homogeneity of variances for the CPUE averages for month and fishing site was corroborated with a one-way ANOVA and applying the Levene's test to the residuals [14]. The Tukey's test was used as posthoc test to determine how average CPUE values differed. The ANOVA was performed with PROC GLM [15].

To discern the environmental structure of the study area, a principal component analysis (PCA) was used. To run the PCA, a matrix of correlations with all fishing sites as dependent variables and all physicochemical and environmental variables studied as independent variables was constructed. The broken-stick eigenvalue model [16] was used to assess the relative interpretability of the ordination results. The PCA was performed in PC-ORD V.3.15 [17]. To determine if the environmental structure modeled the distribution of the white shrimp abundance, the CPUE values were superimposed on maps of the sampling area showing strata of the two most important physicochemical variables identified by PCA.

\section{RESULTS}

The study area was very shallow, with depths not ex- ceeding $5 \mathrm{~m}$ (range: $2-5 \mathrm{~m}$ ). The averages and ranges of the physicochemical variables studied were the following: TR: $46.3 \mathrm{~cm}$, range: $25.2-56.7 \mathrm{~cm} ; \mathrm{T}: 26^{\circ} \mathrm{C}$, range: $23.7^{\circ} \mathrm{C}-29.0^{\circ} \mathrm{C}$; S: $34.5 \mathrm{UPS}$, range: 30.3 - $37.5 \mathrm{UPS}$; DO: $5.63 \mathrm{mg} / \mathrm{l}$, range: $4.28-6.88 \mathrm{mg} / \mathrm{l}$ and POS: $80 \%$, range: $59.2 \%-89.6 \%$. Rainfall accumulated during the study period was $359.5 \mathrm{~mm}$, with a peak of greater intensity between February-March 2009, and another of minor intensity between May-July 2009. According to the scale of Beaufort, the winds measured in the area (average $=$ $5.35 \mathrm{~m} / \mathrm{s}$; range: $4.8-63 \mathrm{~m} / \mathrm{s}$ ) were classified as of grades 3 and 4 (breeze mild to moderate with waves between $21-100 \mathrm{~cm})$.

The PCA identified three components (PC1, PC2, and PC3) with eigenvalues greater than the eigenvalues of the broken-stick model and accounted for $57.5 \%$ of the standardized variability of the data matrix. The PC1, which accounted for $22.1 \%$ of the variability, was represented by the variables $\mathrm{T}$ and $\mathrm{D}$; the PC2, which accounted for $18.5 \%$ of the variability, was represented by rainfall, whereas the PC3 was represented by POS and explained $16.9 \%$ of the variability (Table 1).

Although the ordination of the fishing sites using PCA1 vs. PCA2 (Figure 2) revealed some overlap between some of them along the components, it can be seen as the majority of the fishing sites were grouped along the PCA1, characterized by a temperature-depth gradient, indicating that the physicochemical-environmental structure of the fishing area responded more to the physicochemical variables than to the environmental variables studied. This indicates that the physicochemical structure of the studied area was little affected by rainfall; i.e. the study area maintained its physicochemical structure un-

Table 1. Loadings of individual variables on axes 1, 2, and 3 for the principal component analysis on physicochemical and environmental variables recorded at fishing sites $(\mathrm{N}=56)$ in the fishing zone of the Rio Seco community, Falcon State, Venezuela, September 2008-Novembre 2009. Underlined values represent variables characterizing the axes.

\begin{tabular}{cccc}
\hline Variable & PC1 & PC2 & PC3 \\
\hline Temperature $\left({ }^{\circ} \mathrm{C}\right)$ & $\underline{-0.5480}$ & -0.3833 & 0.0781 \\
Salinity (UPS) & -0.0649 & 0.4783 & 0.4785 \\
Dissolved oxygen (mg/l) & -0.3890 & 0.3094 & -0.0764 \\
Oxygen percent saturation (\%) & -0.3890 & 0.0265 & $-\underline{0.5857}$ \\
Depth (m) & $\underline{0.5480}$ & -0.3582 & 0.1132 \\
Transparency (m) & 0.3548 & 0.0790 & -0.0397 \\
Rainfall (mm) & 0.2286 & $\underline{0.5047}$ & -0.5088 \\
Wind (m/s) & -0.2430 & 0.3723 & 0.3779 \\
Percent of variance explained (\%) & 22.1 & 18.5 & 16.9 \\
\hline
\end{tabular}




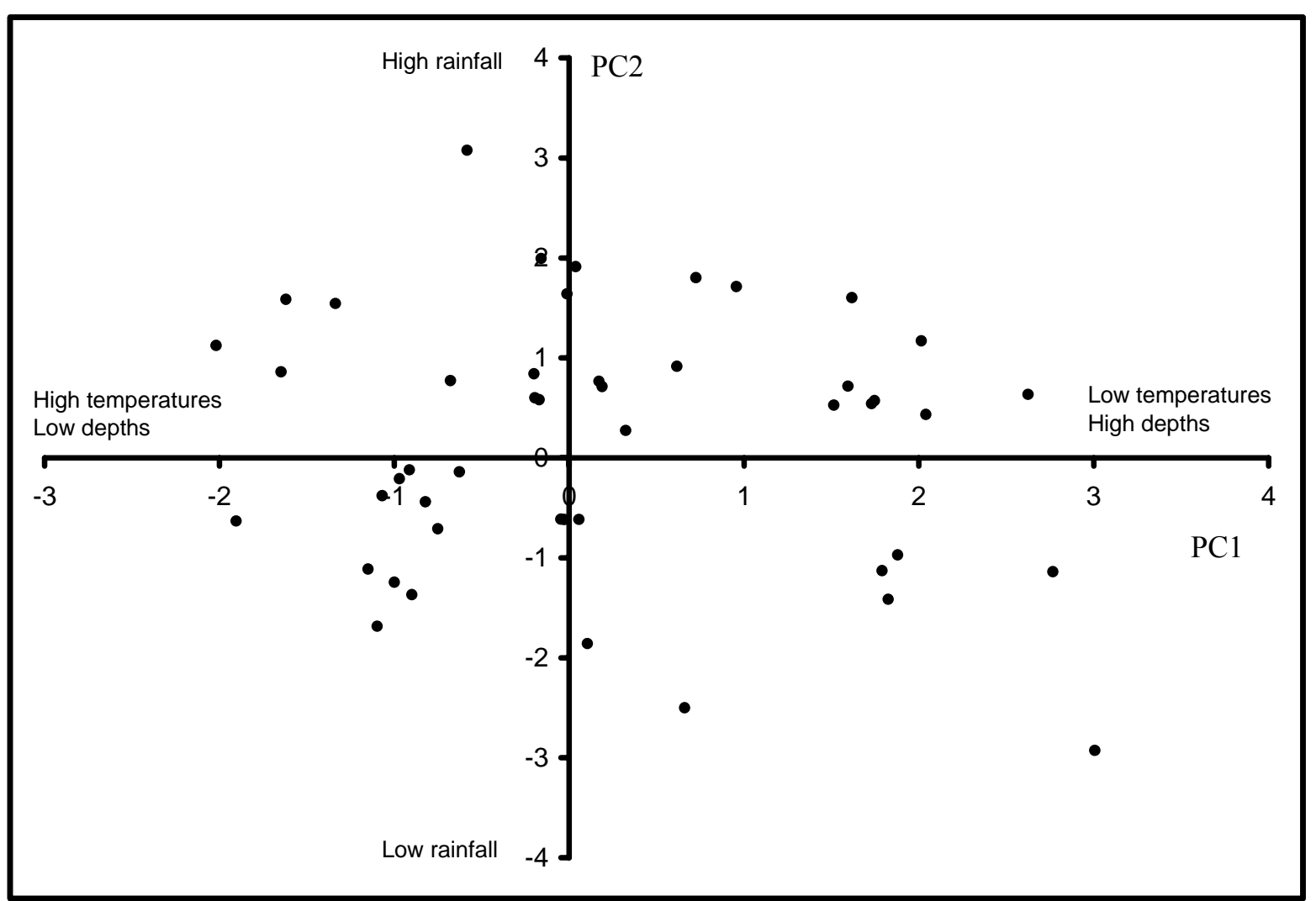

Figure 2. Ordination of the study area according to the first two significant components of principal components analysis for the physicochemical and environmental variables recorded at fishing sites $(\mathrm{N}=56)$ in the fishing zone of the Rio Seco community, Falcon State, Venezuela, September 2008-Novembre 2009. The temperature gradient increases from right to the left, the depth gradient increases from left to the right and the rainfall gradient increases from bottom to the top. Most sites are aligned along the temperature-depth gradient (horizontal axis). Each dot represents a fishing site; due to the overlapping of some dots, not all 56 fishing sites are seen.

altered in the face of environmental phenomena (in this case, rainfall), which finally allows to establish that it is the gradient temperature-depth the primary responsible for modeling the physicochemical structure of the study area.

There were 56 samples taken in the 21 fishing sites in which 2135 individuals were collected. The range of the fishing effort was $53-173 \mathrm{~min}$ (average $=114 \mathrm{~min}$ ). CPUE was highly variable (range: $0.13-6.23 \mathrm{ind} / \mathrm{min}$ ), with two well-defined peaks, one in December 2008 (average $=6.23 \mathrm{ind} / \mathrm{min}$ ) and the other one in June 2009 (average $=3.42 \mathrm{ind} / \mathrm{min}$ ).

The ANOVA confirmed that the CPUE differed significantly among months $(\mathrm{F}=15.6 ; \mathrm{DF}=11 ; P<0.0001)$ but not among fishing areas $(\mathrm{F}=1.52 ; \mathrm{DF}=17 ; P=$ $0.1979)$; the interaction term was also not significant ( $F$ $=0.52 ; \mathrm{DF}=10 ; P=0.8561)$. The Tukey's post hoc test determined that there were three groups where the average CPUE differed temporarily (Table 2).

The superimposing of the CPUE on the temperature and depth strata (Figures 3 and 4) confirmed that the CPUE followed a pattern along these gradients. For ex-
Table 2. Results of the Tukey's post hoc test on average CPUE obtained for all sampling months in the fishing zone of the Rio Seco community, Falcon State, Venezuela, September 2008November 2009. Months with the same letter are not significantly different.

\begin{tabular}{cccc}
\hline Letter & Mean & N & Month \\
\hline A & 6.23 & 5 & December \\
B & 3.53 & 6 & January \\
B & 3.42 & 5 & June \\
C & 1.48 & 5 & March \\
C & 0.86 & 8 & November \\
C & 0.57 & 5 & October \\
C & 0.39 & 2 & May \\
C & 0.32 & 4 & February \\
C & 0.29 & 4 & April \\
C & 0.26 & 4 & July \\
C & 0.21 & 5 & August \\
C & 0.13 & 3 & September \\
\hline
\end{tabular}




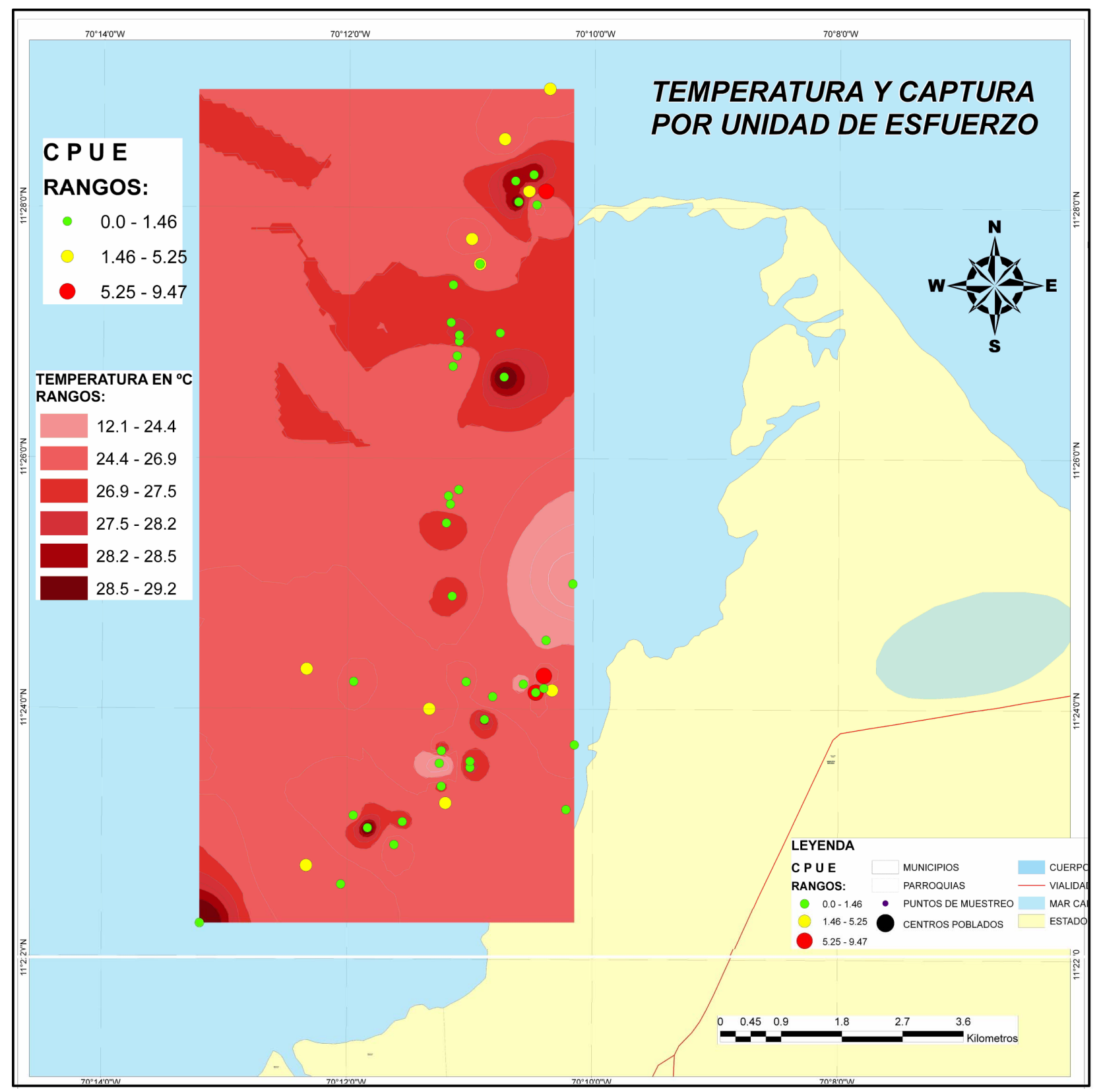

Figure 3. Superimposing of the CPUE on temperature strata identified in the fishing zones of the fishing community of Rio Seco, Falcon State, Venezuela, September 2008-November 2009. Three strata of CPUE and six strata of temperature are delineated.

ample, the highest values of CPUE were observed in the $2.2-3.3 \mathrm{~m}$ depth stratum and in the $24.4^{\circ} \mathrm{C}-26.9^{\circ} \mathrm{C}$ temperature stratum. This indicated that the white shrimp showed greater preference by intermediate depths and temperatures.

\section{DISCUSSION}

The effects of environmental parameters on the distribution patterns of aquatic organisms have been frequently studied in fisheries science [18-24]. Most of these studies were based on extensive time series (sev- eral years), in contrast to our study which only analyzed a database of 15 months. However, our results revealed a strong relation between catches and the physicochemical variables studied.

The superimposing of the CPUE on the strata of temperature and depth clearly indicated that the distribution of white shrimp in the study area responded to the direct effect of these physicochemical variables. This behavior has been reported by other researchers for the white shrimp; for example, Santos et al. [25], pointed out that the water temperature of an estuary in the State of Sao Paulo, Brazil, was decisive in variations of the abun- 


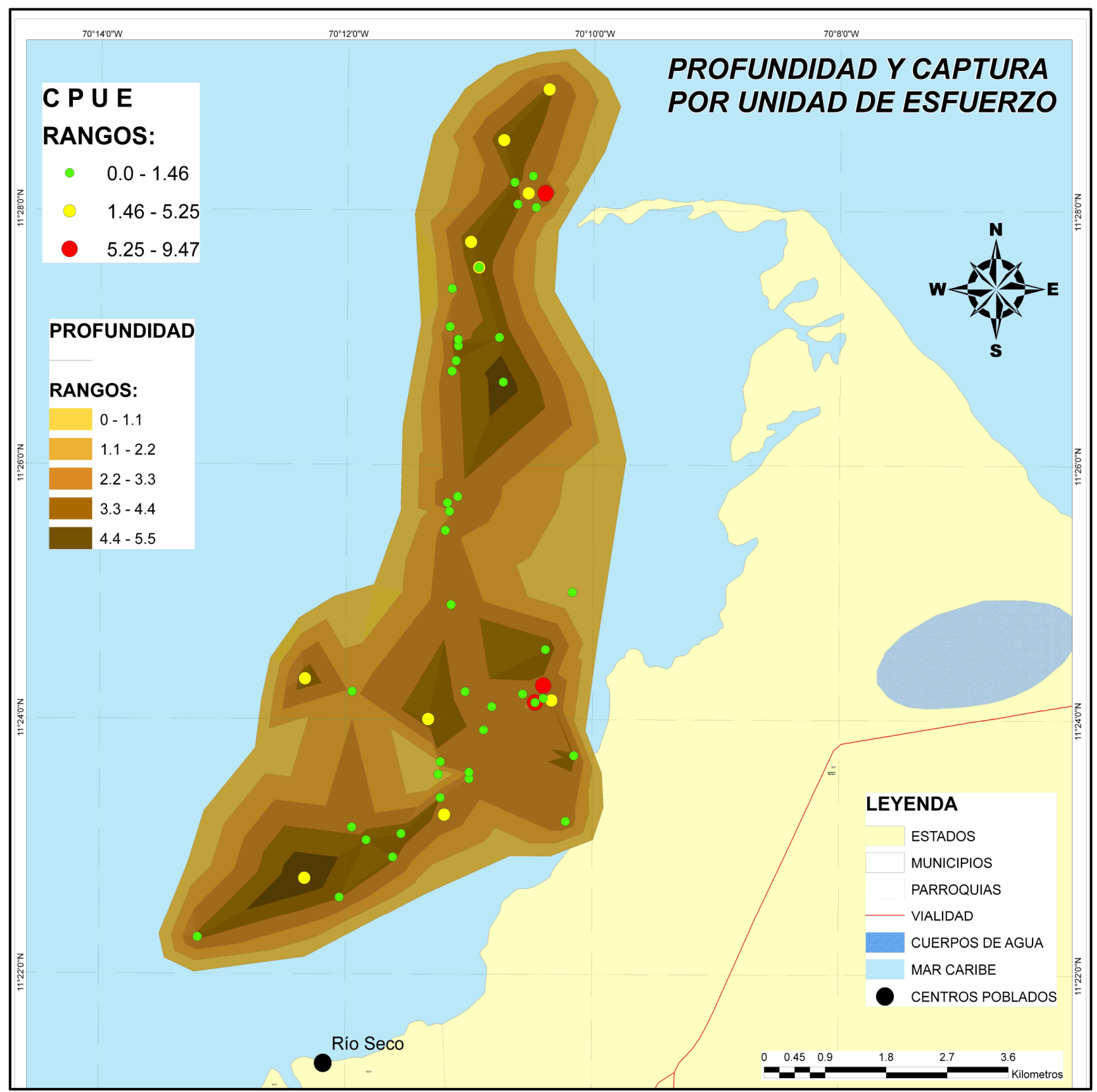

Figure 4. Superimposing of the CPUE on depth strata identified in the fishing zones of the fishing community of Rio Seco, Falcon State, Venezuela, September 2008-November 2009. Three strata of CPUE and five strata of depth are delineated.

dance of this species, being greatest during the summer, when water temperatures were higher. On the other hand, these same investigators indicated that the abundance of white shrimp was constant along the gradient of depth of the estuary, although samples taken in open sea (more than $15 \mathrm{~m}$ depth) indicated that the abundance of this species decreased with depth.

It is evident that the CPUE-temperature-depth relations could be related to other variables not evaluated in this work; e.g., the type of bottom (texture and organic content), which is fundamental for shrimps when they are buried [26]. Another important element not evaluated was marine currents, responsible for the sedimentary deposits and transportation, distribution and concentration of nutrients, and the distribution and displacement of organisms. According to Santos et al. [25], variations in the characteristics of the seabed are associated with depth; shrimps select shallower muddy zones as feeding and shelter areas, whereas select zones of greater depth (bottoms of sand and silt), as reproduction areas.

In addition, in general terms, the behavior of the CPUE during the study could reflect the effect of the 
empirical knowledge of fishers, who work in areas where their experience indicates they have high yields, thus overestimating the CPUE. However, and despite the nature of the experimental design applied in the study haphazardly, there was not a prevailing trend of high CPUE in specific sites, a situation confirmed by the ANOVA applied to the CPUE by fishing sites, which reduced the possibility of overestimation or underestimation of the CPUE for the study area.

\section{Management Implications}

With the increasing fishing pressure globally, understanding the influence of the environment on the survival and abundance of fishery resources is of vital importance, both for the fisheries management and to the environment itself. Environmental factors and natural phenomena lead to fluctuations in the capture from year to year, or in periods of longer duration, and in a nonpredictable manner, increasing the exposure of the fishery and resources to the dangers of overexploitation and eventual collapse [27].

Our data identified a close relationship between CPUE and the physicochemical structure of the study area. It is clear that these results respond to a specific physicochemical and fishing structure; i.e., we measured and analyzed relevant information during the 15 months our study lasted, therefore we cannot ensure that this is the average reality of the fishery. It goes without saying that a temporarily broader study is necessary to clarify this situation. However, our results suggest that the modification of the physicochemical structure of the study area could lead to significant, probably negative, effects on the fishery. The EBFM perspective calls for an ecologically functional ecosystem that can support fisheries, and the only way to keep functionally active ecosystems is avoiding its indiscriminate intervention.

In 2009 an aqueduct crossing part of the study area was constructed, which involved significant environmental effects. There are some evidences, provided through local ecological knowledge, pointing to negative effects of the construction of the aqueduct on some fisheries. For example, the crevalle jack (Caranx hippos) performs a mid-year annual migration through the coasts of the Gulf of Venezuela in direction northwest $\rightarrow$ southwest $\rightarrow$ southeast $\rightarrow$ northeast, entering into the Golfete de Coro. This migration route of the crevalle jack is a recruitment to the area allowing the fishing communities of the Gulf of Venezuela and Golfete de Coro its exploitation. The fishers of the zone ensured that in 2009 the crevalle jack did not enter the Golfete de Coro, scared away by the noise of the machinery (shovels, drills, barges, among others) used in the construction of the aqueduct, despite having done its normal migration through the Gulf of Venezuela and based in references of catches of the species during that period by the communities that are outside of the Golfete [28].

On the other hand, the extremely shallow condition of the study area exposes it to extreme variations of salinity and turbidity as a consequence of the Mitare River discharge $[29,30]$. This very shallow condition could lead to loss of depth due to the installation of oil equipments projected for the near future and the possible intervention of the Mitare River. For example, the so called project Suministro Falcon-Zulia (SUFAZ) of Petroleos de Venezuela, S.A. (PDVSA) contemplates the construction of a multiuse pipeline of 24 inches in diameter for the transport of petroleum products whose submarine route is expected to traverse the study area. If the SUFAZ project is implemented as planned, and given the precedent of the construction of the aqueduct, PDVSA should take measures to minimize or mitigate its impact on the fisheries of the zone, particularly on the white shrimp fishery.

\section{REFERENCES}

[1] Christensen, N.L., Bartuska, A.M., Brown, J.H., Carpenter, S., D'Antonio, C., Francis, R., Franklin, J.F., MacMahon, J.A., Noss, R.F., Parsons, D.J., Peterson, C.H., Turner, M.G. and Woodmansee, R.G. (1996) The report of the Ecological Society of America committee on the scientific basis for ecosystem management. Ecological Applications, 6, 665-691. doi:10.2307/2269460

[2] Larkin, P.A. (1996) Concepts and issues in marine ecosystem management. Reviews in Fish Biology and Fisheries, 6, 139-164. doi:10.1007/BF00182341

[3] Wiff, R. and Quiñones, R.A. (2004) Parametrización ambiental en modelos biológico-pesqueros. Una revisión. Gayana, 68, 76-92.

[4] United States National Research Council (1998) Sustaining marine fisheries. A Report of the Committee on Ecosystem Management for Sustainable Fisheries, Ocean Studies Board, Commission on Geosciences, Environment and Resources, National Research Council, Washington DC.

[5] Garcia, S.M., Zerbi, A., Aliaume, C., Do Chi, T. and Lasserre, G. (2003) The ecosystem approach to fisheries. Issues, terminology, principles, institutional foundations, implementation and outlook. FAO Fisheries Technical Paper No. 443, FAO, Rome.

[6] Pikitch, E.K., Santora, C., Babcock, E.A., Bakun, A., Bonfil, R., Conover, D.O., Dayton, P., Doukakis, P., Fluharty, D., Heneman, B., Houde, E.D., Link, J., Livingston, P.A., Mangel, M., McAllister, M.K., Pope, J. and Sainsbury, K.J. (2004) Ecosystem-based fishery management. Science, 305, 346-347. doi:10.1126/science.1098222

[7] FAO EAF-Nansen Project (2010) Report of the annual forum of the EAF-Nansen project. Theme: The Ecosystem Approach to Fisheries-Opportunities for Africa, Rome, 
16 December 2008, FAO EAF-Nansen Project Report No 5.

[8] National Marine Fisheries Service (1998) Ecosystembased fishery management. A Report to Congress by the Ecosystem Principles Advisory Panel as Mandated by the Sustainable Fisheries Act Amendments to the MagnusonStevens Fishery Conservation and Management Act, Seattle, Washington DC, 1996.

[9] Zeigler, J. (1964) The hidrography and sediments of the Gulf of Venezuela. Limnology and Oceanography, 9, 397-411. doi:10.4319/10.1964.9.3.0397

[10] Ginés, Hno., Monente, J., Lozano, A., Breman, E., Voltolin, D., Prinoz, D., González, L., Jiménez, C., Brownell, W., Pastor, G., Gutiérrez, P., Guedez, T. and Mago, F. (1982) Carta pesquera de venezuela. II. Áreas central y occidente. Fundación La Salle de Ciencias Naturales Monografías, Caracas.

[11] Pérez-Farfante, I. (1970) Claves ilustradas para la identificación de los camarones comerciales de la América Latina. Instituto Nacional de Investigaciones Pesqueras, Serie Divulgación, México.

[12] Fisher, W. (1978) FAO species identification sheets for fishery purpose. Western Central Atlantic (Fishing Area 31). FAO, Roma.

[13] Rodríguez, G. (1980) Los crustáceos decápodos de Venezuela. Instituto Venezolano de Investigaciones Científicas (IVIC), Caracas.

[14] Milliken, G.A. and Johnson, D.E. (1984) Analysis of messy data. Volume 1: Designed experiments. Van Nostrand Reinhold Company, New York.

[15] Statistical Analysis System (SAS) (2006) SAS/STAT Version 9.2. SAS Institute, Inc., Cary.

[16] Jackson, D.A. (1993) Stopping rules in principal components analysis: A comparison of heuristical and statistical approaches. Ecology, 74, 2204-2214. doi:10.2307/1939574

[17] McCune, B. and Mefford, M.J. (1997) Multivariate analysis of ecological data. Version 3.15 MJM Software, Gleneden Beach, Oregon.

[18] Ratz, H.J. (1996) Relevance of some environmental parameters to distribution patterns of groundfish and implications for reasonable survey design: Case study Atlantic cod off Greenland. NAFO Scientific Council Studies, 28, 73-78.

[19] Brill, R.W. and Lutcavage, M.E. (2001) Understanding envrionmental influences on movements and depth distributions of tunas and billfishes can significantly improve population assessments. American Fisheries Society Symposium, 25, 179-198.

[20] Pombo, L., Elliot, M. and Rebelo, J.E. (2005) Environmental influences on fish assemblage distribution of an estuarine coastal lagoon, Ria de Aveiro (Portugal). Scien- tia Marina, 69, 143-159.

[21] Reguzzoni, J. (2007) Assessing the relationship between environmental conditions and the blue crab fishery in relation to restoration goals for the Caloosahatchee River. Annual Report, Agreement No: OT050973, West Palm Beach.

[22] Childs, A.R., Cowley, P.D., Naesje, T.F., Booth, A.J., Potts, W.M., Thorstad, E.B. and Okland, F. (2008) Do environmental factors influence the movement of estuarine fish? A case study using acoustic telemetry. Estuarine, Coastal and Shelf Science, 78, 227-236. doi:10.1016/j.ecss.2007.12.003

[23] Párraga, D.P., Cubillos, L.A. and Correa-Ramirez, M.A. (2010) Variaciones espacio-temporales de la captura por unidad de esfuerzo en la pesquería artesanal costera del pargo rayado Lutjanus synagris, en el Caribe colombiano y su relación con variables ambientales Revista de Biología Marina y Oceanografía, 45, 77-88.

[24] Lee, H.H. and Brodziak, J. (2011) Investigation of the association between Hawaii Deep Slope bottomfish CPUE and environmental variables. PIFSC Internal Report IR-11-019.

[25] Santos, J., Severino, E. and Vaz Dos Santos, A. (2008) Estructura populacional do camaró-branco Litopenaeus schmitti nas regiones estuarina e marinha da Baixada Santista, Sao Paulo, Brasil. Boletim do Instituto de Pesca Sao Paulo, 34, 375-389.

[26] Costa, R., Fransozo, A. and Pinheiro, A. (2004) Ecological distribution of the shrimp Pleoticus muelleri (Bate, 1888) (Decapoda: Penaeoidea) in southeastern Brazil. Hydrobiologia, 529, 195-203. doi:10.1007/s10750-004-6410-x

[27] Csirke, J. (1997) Retos para la pesca mundial de captura con posibilidades limitadas de expansión. Departamento de Pesca FAO.

http//fao.org/Regional/LAmerica/prior/recnat/recursos/pe sca/csirke.htm

[28] Álvarez, F. (2012) Caracterización preliminar de la ecología pesquera del Golfete de Coro, Venezuela: Una herramienta para el manejo y la validación del conocimiento local. Trabajo Especial de Grado para obtener el grado de Magister Scientiarum en Ciencias Biológicas, Universidad del Zulia, Maracaibo.

[29] Ferrer, C.A., Quintero, A., Ferrer, R.A., Pomares, O., Terejova, G., Ferrer, A., Guerra, J. and Leal, M. (2006) Estudio de impacto ambiental y sociocultural del proyecto acueducto bolivariano del estado falcón, tendido golfete de coro. Esambient-Hidrofalcón, Falcón.

[30] Petito Quintavalle, M. (2007) Estudio de geofísica de alta resolución y batimetría, fase de detalle desde Punta Cardón hasta el sector Punta Cechepa. Proyecto de Grado para optar al Título de Ingeniero Geofísico. Universidad Simón Bolívar, Sartenejas, Caracas. 